\section{Ureaseaktivität bei Streptomyceten}

\section{B. Nitsch und H. J. KutzNER}

Institut für Mikrobiologie, Technische Hochschule Darmstadt

(Z. Naturforsch. 23 b, 565 [1968] ; eingegangen am 7. Dezember 1967)

Die Fähigkeit zur Spaltung von Harnstoff durch das Enzym Urease ist bei Mikroorganismen weit verbreitet und wird in einigen Fällen auch als taxonomisches Merkmal verwendet, z. B. zur Abgrenzung der Gattung Proteus von anderen Enterobakterien, innerhalb der Gattung Bacillus sowie auch in der Gattung Sarcina ${ }^{1}$. Mehrere Autoren untersuchten die Verwertbarkeit von Harnstoff als N-Quelle für das Wachstum von Streptomyceten ${ }^{2-5}$. Während in diesen Fällen Harnstoff in Konzentrationen von etwa 0,05 bis maximal $2 \mathrm{~g} / l$ verwendet und die Verwertbarkeit an Hand der Wachstumsstärke beurteilt wird, beträgt die Harnstoffkonzentration bei Tests auf Urease bei den verschiedenen Bakterien $20 \mathrm{~g} /$ Liter. Eine Urease-Aktivität wird durch Erhöhung der Reaktion von $\mathrm{pH}$ 6,8 auf $>8$ innerhalb von wenigen Stdn. bis wenigen Tagen erkannt (Umschlag von Phenolrot von gelb nach rot). Ein derartiger Test wurde bei Streptomyceten bisher nur von Afanasiev ${ }^{6}$ durchgeführt (5 g Harnstoff/l). Diese Beobachtungen scheinen jedoch in Vergessenheit geraten zu sein, und in keiner der zahlreichen taxonomischen Untersuchungen über Streptomyceten der letzten 20 Jahre wurde dieser Test verwendet. Lediglich MARIAT ${ }^{7}$ untersuchte zahlreiche aerobe, pathogene Actinomyceten auf Urease-Aktivität, und Hopwood ${ }^{8}$ verwendete Ureasebildung als genetischen "marker" bei $S$. violaceoruber.

Wir prüften bisher etwa 250 Streptomyces-Stämme (davon etwa 100 mit Artnamen versehene Kulturen aus verschiedenen Sammlungen) auf Urease-Aktivität, wobei wir im wesentlichen das von Christensen ${ }^{9}$ entwickelte Medium verwendeten. In zahlreichen Versuchen wurden jedoch auch Modifikationen dieses Mediums vorgenommen: (a) Zusammensetzung des Basal-

1 R. S. Breed, E. G. O. Murray u. N. R. Smith, Bergey's Manual of Determinative Bacteriology. 7. Aufl. The Williams and Wilkins Co., Baltimore 1957.

2 S. A. Waksman, J. Bacteriol. 5, 1 [1920].

3 C. Stapp u. G. Spicher, Zbl. Bakteriol., II. Abt. 108, 19 [1954].

4 P. R. Burkholder, S. H. Sun, J. Ehrlich u. L. Anderson, Ann. N. Y. Acad. Sci. 60, 102 [1954]. mediums (Ersatz des Peptons durch $\mathrm{NH}_{4} \mathrm{Cl}$ oder Harnstoff als alleinige N-Quelle), (b) Pufferkapazität $(n / 10$, $n / 20$ - und $n / 45$-Phosphatpuffer), (c) Anfangs-pH $(6,4$ und 6,8), (d) Indikator (Thymolblau oder Phenolphthalein an Stelle des Phenolrot), (e) Konsistenz (Agar-Schrägröhrchen - halbfestes Medium mit 0,3\% Agar in kleinen Reagenzröhrchen, Impfmaterial in die oberen $2 \mathrm{~mm}$ eingebracht). Am besten bewährte sich bisher das Christensensche Medium mit n/45Phosphatpuffer von $\mathrm{pH} \mathrm{6,8,} \mathrm{halbfest.} \mathrm{Die} \mathrm{bisherigen}$ Ergebnisse, deren ausführliche Veröffentlichung in Zbl. Bakt. II. Abt. vorgesehen ist, lassen sich wie folgt zusammenfassen:

(a) Es gibt sehr aktive Harnstoffspalter, die innerhalb von 12 bis 24 Stdn. einen intensiven Farbumschlag des Indikators hervorrufen (z. B. S. griseus - Streptomycinbildner, S. violaceoruber). Infolge der schnell erhöhten Reaktion - $\mathrm{NH}_{3}$-Geruch ist wahrnehmbar kommen diese Kulturen über ein geringes Anfangswachstum nicht hinaus. Bei dieser Gruppe von Stämmen kommt es bei Schrägagarkulturen nach 2 bis 3 Tagen zur Bildung von Kristallen, die auch früher ${ }^{6}$ beobachtet und als Magnesiumammoniumphosphat identifiziert worden waren. (b) Eine zweite Gruppe von Stämmen zeigt eine langsame, nach 2 bis 3 Tagen einsetzende und meist auch nicht so intensive Harnstoffspaltung: die hohe Schicht des halbfesten Mediums ist nur 1 bis $2 \mathrm{~cm}$ tief rot gefärbt; auf Schrägagar tritt keine oder nur eine spärliche Kristallbildung auf (z. B. S. griseus - Griseinbildner, S. venezuelae, S. lavendulae). (c) Mehrere Streptomyceten verursachen auch nach 4 bis 5 Tagen keinen Farbumschlag oder nur Spuren einer Rotfärbung; offenbar vermögen sie nicht Harnstoff zu spalten (z. B. S. fradiae, S. aureofaciens).

Wenn es sich bei diesem Test auch nicht um eine „Alles-oder-Nichts-Reaktion“ handelt und über die Variation der Harnstoffspaltung innerhalb einer Art noch keine endgültige Aussage gemacht werden kann, so stellt diese Eigenschaft doch eine Bereicherung des Bestandes an physiologischen Merkmalen für die Charakterisierung von Streptomyceten dar.

5 R. Shinobu, Mem. Osaka Univ. Liberal Arts and Educ., B. Natural Sci. Nr. 7, 1 [1958].

6 M. M. Afanasiev, Nebraska agric. Exp. Station Res. Bull. 92, 1 [1937].

7 F. Mariat, Ann. Inst. Pasteur 105, 795 [1963].

8 D. A. Hopwood, Microbiol gen. Bull. 20, 7 [1964].

9 W. B. Christensen, J. Bacteriol. 52, 461 [1946]. 